Copying: This journal is registered with the Copyright Clearance Center, 27 Congress St., Salem, Mass. 01970. Organizations in the USA who are also registered with C.C.C. may therefore copy material (beyond the limits permitted by sections 107 and 108 of US copyright law) subject to payment to C.C.C. of the per copy fee of $\$ 5.00$. This consent does not extend to multiple copying for promotional or commercial purposes. Code 0261-1430 $\$ 5.00+0.00$

ISI Tear Sheet Service, 3501 Market Street, Philadelphia, Pennsylvania 19104, USA, is authorized to supply single copies of separate articles for private use only.

For all other use, permission should be sought from the Cambridge or New York offices of the Cambridge University Press.

Notes for contributors. The top (ribbon) copy of the typescript should be submitted. This must be double spaced with margins of at least $I^{\prime \prime}$. Footnotes, bibliographies, appendixes and indented quotations must also be double spaced. Contributors should write in English, or be willing to have their articles translated.

Tables, graphs, diagrams and music examples must be supplied on separate sheets. Illustrations should be in the form of black and white glossy prints, ideally measuring $8 " \times 6^{\prime \prime}$. All illustrative material should be numbered and carefully keyed into the typescript. Captions should be typed double spaced on separate sheets.

Bibliographical material. The method of citation is author-date system (Smith 1980, p. 66), which should be given in the text rather than in footnotes; full references should be listed at the end of each article. Abbreviations for the names of periodicals, libraries etc. should not be used without explanation.

For more detailed matters of style please follow the practices of A Manual of Style, 12th edn (Chicago: University of Chicago Press, 1969). 


\section{Center for Black Music}

\section{Research}

\section{Columbia College Chicago}

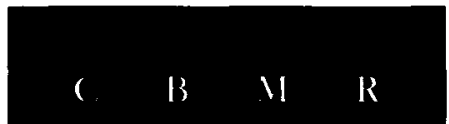

Beginning in $1988 \ldots$

Two issues of Black Music Research Journal will appear in spring and fall. Papers from the 1987 National Conference on Black Music Research will be published, featuring articles related to black music in New Orleans-jazz, religious music, rhythm and blues, Creole and Cajun music, zydeco, and nineteenth-century concert and recital music.

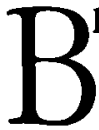

lack Music Research Newsletter will appear under a new name-Black Music Research Bulletin; its contents will reflect the publication's trend toward more substantive, preliminary research articles and columns.
$A^{\text {new }}$
new publication, CBMR Digest, will be issued free of charge to all of the Center's subscribers and interest to black music scholars and researchers and information about the Center for Black Music Research and its activities.

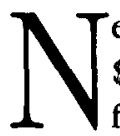

ew subscription rates for BMR Journal will be $\$ 15.00$ for domestic subscribers and $\$ 20.00$ for foreign subscribers. The rates for BMR Bulletin will be $\$ 3.00$ for domestic subscribers and $\$ 5.00$ for foreign subscribers. Send subscriptions or requests for further information to:

Subscriptions Manager, CBMR Publications, Center for Black Music Research Columbia College Chicago, 600 South Michigan Avenue, Chicago, IL 60605-1996. (312) 663-9462. 